\title{
Pregnant Women's Blood Pressure Reactivity Differences With and Without Family History of Hypertension After Undergoingthe Cold Pressor Test (CPT)
}

\author{
$1^{\text {st }}$ Linda Yanti \\ Midwifery Program \\ Universitas Harapan Bangsa \\ Purwokerto, Indonesia \\ lindayanti@uhb.ac.id
}

\author{
$2^{\text {nd }}$ Mariah Ulfah \\ Nusing Departement \\ Universitas Harapan Bangsa \\ Purwokerto, Indonesia \\ mariahulfah@uhb.ac.id
}

\author{
$3^{\text {rd }}$ Made Suandika \\ Nusing Departement \\ Universitas Harapan Bangsa \\ Purwokerto, Indonesia \\ gelansatra@gmail.com
}

\begin{abstract}
Pregnancy may physiologically trigger pregnant women's cardio-vascular system to progressively adapt with significant structural and functional changes, such as increasing blood volume, cardiac output, heart rate and stroke volume as well as decreasing blood pressure and systemic vascular resistance, including hypertension which is possibly triggered by family history of hypertension. The Cold Pressor Test (CPT) was conducted to see pregnant women's blood pressure reactivity differences with and without family history of hypertension. This research aims at examining pregnant women's blood pressure reactivity differences with and without family history of hypertension after undergoing the Cold Pressor Test (CPT). This quasi-experimental research measured both systolic and diastolic blood pressure changes before and after undergoing the Cold Pressor Test (CPT), while the data was processed using Mann-Whitney test. Results: Of 80 pregnant women's mean systolic blood pressure with family history of hypertension before and after undergoing the Cold Pressor Test (CPT)was respectively $103.82 \mathrm{mmhg}$ and $126.76 \mathrm{mmhg}$, while, their mean diastolic blood pressure before and after undergoing the Cold Pressor Test (CPT) was respectively $76.62 \mathrm{mmhg}$ and $\mathbf{1 0 0 . 2 9} \mathrm{mmhg}$. The pregnant women's mean systolic blood pressure without family history of hypertension before and after undergoing the Cold Pressor Test (CPT) was $107.91 \mathrm{mmHg}$ and $118.87 \mathrm{mmHg}$ while their mean diastolic blood pressure before and after undergoing the Cold Pressor Test (CPT) was respectively 76.62 $\mathrm{mmHg}$ and $78.50 \mathrm{mmHg}$. After the data was processed using Mann-Whitney test it showed a significance value of0.003. Because the p-value was $<0.05$, it can be concluded that there was a significant difference between pregnant mothers with and without family history of hypertension and those with both systolic hypo-reactor and hyper-reactor. Conclusion: there is a significant difference between pregnant women with and without family history of hypertension and blood pressure.
\end{abstract}

Keywords-blood pressure reactivity, pregnant women, Cold Pressor Test

\section{INTRODUCTION}

Pregnancy may physiologically trigger pregnant women's cardio-vascular system to progressively adapt including with the risk of hypertension. Therefore,
Complication management and prevention related to pregnancy are greatly important to improve the women's health. Hypertension commonly happens in pregnancy up to $10 \%$ of pregnancies in the world with the increasing prevalence. The hypertension conditions include gestational hypertension, preeclampsia, chronic hypertension in pregnancy, and chronic hypertension with superimposed preeclampsia [1]. Hypertension disorder in pregnancy is one major cause of maternal, fetal, and neonatal morbidity and mortality throughout the world Many factors influence hypertension, such as environment, sympathetic nervous system hyperactivity, renin-angiotensin system, $\mathrm{Na}$ excretion defects, increasing $\mathrm{Na}$ and $\mathrm{Ca}$ intracellular, and other increasing risks, such as obesity, smoking, and genetic [4]. The development of hypertension is strongly influenced by many factors including lack of physical activities, family history, and bad eating habits, such as eating with high animal fat, lack of fiber, high sodium and low potassium content [2].

Early detection to an individual with high risk of hypertension is greatly important for preventive action. Cardiovascular hyper-reactivity to stress has been hypothesized as one important risk factor for the development of hypertension and cardiovascular disease. Cold Pressor Test (CPT), which measures the blood pressure reactivity (BP) to the external cold stimuli, has been commonly used to evaluate the cardiovascular reactivity to stress in normotensive and hypertensive subjects [3]. The incidence of maternal mortality in Banyumas Regency in 2018 increased to 18 people from the previously 14 people in 2017. At the beginning of 2019 to October 2019, there were seven maternal deaths with $57.14 \%$ was caused by hypertension. Of 18 maternal deaths, $55.5 \%$ was caused by hypertension [6].

The incidence of hypertension may be predicted using the "Cold Pressor Test", a provocation test for patients with cold temperatures affecting the vasomotor center. According to Schirger (1994) in Sharon (2009), if the "Cold Pressor Test" is found positive in a person, he or she has the possibility of suffering from essential hypertension [7]. According to Kasagi, Akahishi, and Shimakao (1995) in 
Irfannudin and Novita (2009), the results of Cold Pressor Test (CPT) might predict the incidence of hypertension in the future [8]. According to the prospective studies conducted by Wood, Sheps, Evelback, and Schirger in Minnesota (19341979), for 45-year on 142 subjects, a positive response to the Cold Pressor Test (CPT) potentially predicted the incidence of hypertension [4] [5].

\section{METHOD}

This a quasi-experimental research compared two treatment groups consisting of pregnant women with and without family history of hypertension and measured the systolic and diastolic blood pressure changes after undergoing the Cold Pressor Test (CPT). This research was conducted at Kembaran Community Health Center 2, Purbandana Village, Kebaran District, Banyumas Regency. The population of this research was pregnant women in the first trimester. The research samples were all the research population with a total of 80 people. The samples were collected using a random sampling technique with the inclusion criteria of patients in the first trimester pregnancy. The Mann-Whitney test was conducted to analyze the not normally distributed data using 2 independent variables [10]. This research has passed the ethical test by the health research ethics committee of Universitas Harapan Bangsa.

\section{RESUlt AND Discussion}

The results of this study were described as follows:

\section{A. Blood pressure characteristics of pregnant women with and without family history of hypertension}

TABLE I. MEAN BLOOD PRESSURE OF PREGNANT WOMEN WITH AND WITHOUT FAMILY HISTORY OF HYPERTENSION

\begin{tabular}{|c|c|c|c|}
\hline Variable & $\mathbf{N}$ & Mean & P value \\
\hline $\begin{array}{lll}\text { With Family } & \text { History } & \text { of } \\
\text { Hypertension } & & \\
\end{array}$ & \multirow[t]{7}{*}{34} & & \\
\hline Systolic Blood Pressure & & & \\
\hline Before CPT & & 103,82 & 0,003 \\
\hline After CPT & & 126,76 & \\
\hline Diastolic Blood pressure & & & \\
\hline Before CPT & & 76,62 & \\
\hline After CPT & & 100,29 & \\
\hline \multicolumn{4}{|l|}{$\begin{array}{l}\text { Without Family } \\
\text { Hypertension }\end{array}$} \\
\hline Systolic Blood pressure & & & 0,000 \\
\hline Before CPT & & 107,91 & \\
\hline After CPT & & 118,87 & \\
\hline Diastolic Blood pressure & & & \\
\hline Before CPT & & 76,72 & \\
\hline After CPT & & 78,50 & \\
\hline & 80 & & \\
\hline
\end{tabular}

Based on table 1, it showed that pregnant women with family history of hypertension before and after undergoing the Cold Pressor Test had the systolic blood pressure of respectively $103.82 \mathrm{mmhg}$ and $126.76 \mathrm{mmhg}$, while their mean diastolic blood pressure was respectively76.62 mmhg and100.29 mmhg. Pregnant women without family history of hypertension before and after the Cold Pressor Test had the systolic blood pressure of respectively $107.91 \mathrm{mmHg}$ and $118.87 \mathrm{mmHg}$, while their mean diastolic blood pressure was respectively $76.62 \mathrm{mmHg}$ and $78.50 \mathrm{mmHg}$.

\section{B. Pregnant women's blood pressure reactivity differences with and without family history of hypertension after undergoing the Cold Pressor Test}

TABLE II. IN PREGNANT WOMEN'S BLOOD PRESSURE REACTIVITY DIFFERENCES WITH AND WITHOUT FAMILY HISTORY OF HYPERTENSION AFTER UNDERGOING THE COLD PRESSOR TEST

\begin{tabular}{|l|l|l|l|}
\hline \multicolumn{1}{|c|}{ Variable } & N & Mean & P value \\
\hline $\begin{array}{l}\text { Systolic Blood } \\
\text { pressure }\end{array}$ & & & \\
\hline Hipo-reactor & 48 & 35,17 & 0,003 \\
\hline Hyper-reactor & 32 & 48,50 & \\
\hline $\begin{array}{l}\text { Diastolic Blood } \\
\text { pressure }\end{array}$ & & & \\
\hline Hipo-reactor & 36 & 27,94 & 0,000 \\
\hline Hyper-reactor & 44 & 50,77 & \\
\hline
\end{tabular}

Based on the result of normality test, both pregnant women with and without family history of hypertension showed that the p-value was below the significant value of 0.05 ( $p<0.05$ ). It showed that the data was not normally distributed that the non-parametric test was conducted using both Wilcoxon and Mann Whitney test. Cold Pressor Test (CPT) was used as a reference to predict hypertension in pregnancy. The results of Mann-Whitney test showed a significance value of 0.003 . Because the p-value was $<0.05$, it might be concluded that there was significant difference between pregnant women with family history of hypertension and those with systolic hypo-reactor and hyperreactor. The result of Mann-Whitney test showed a significance value of 0.000 . Because the p-value was $<0.05$, it might be concluded that there was a significant difference between mothers with family history of hypertension and those with diastolic hypo-reactor and hyper-reactor. It might be concluded that there was a significant difference between pregnant women with and without family history of hypertension and their blood pressure.

Based on table 1, it showed that pregnant women with family history of hypertension before and after undergoing the Cold Pressor Test had the systolic blood pressure of respectively $103.82 \mathrm{mmHg}$ and $126.76 \mathrm{mmHg}$, while their mean diastolic blood pressure was respectively $76.62 \mathrm{mmHg}$ and $100.29 \mathrm{mmHg}$. Pregnant women without family history of hypertension before and after undergoing the Cold Pressor Test (CPT) had the systolic blood pressure of respectively $107.91 \mathrm{mmHg}$ and $118.87 \mathrm{mmHg}$, while their mean diastolic blood pressure was respectively $76.62 \mathrm{mmHg}$ and 78.50 $\mathrm{mmHg}$.

Cold temperature and stress were known affecting the blood pressure (BP) and heart rate. This research was in line with that conducted by Hada Amatya, et all [11] In this research, the students conducted the Cold Pressor Test to show the blood pressure (BP) changes following the environmental pressures. In the Cold Pressor Test (CPT), the respondents immersed one of their hands into the ice water for 1-2 minutes, while the group members monitored the 
respondents' blood pressure (BP) changes from the beginning until the recovery period. Temperature and other environmental stressors were known affecting the heart rate and blood pressure. For example, the sudden and increasingly painful Cold Pressor Test (CPT) caused a massive release of sympathetic nervous system and norepinephrine. This sympathetic release triggers the cardiovascular system's (CV's) responses including arteriolar constriction as well as increasing blood pressure and cardiac contractility. During cold water immersion, the initial skin vasoconstriction resulted in the increasing HR and arterial blood pressure (approximately $15 \mathrm{mmHg}$ increase in Diastolic Blood Pressure) [1]. The Cold Pressor Test (CPT) had shown dilating the normal respondents' coronary arteries respondents, yet narrowing the hypertensive respondents' coronary arteries [12].

Based on table 2, the results showed that there was a significant difference between pregnant women with and without family history of hypertension and blood pressure. Hypertension is influenced by several factors such as environment, sympathetic nervous system hyperactivity, renin-angiotensin system, $\mathrm{Na}$ excretion defects, increasing $\mathrm{Na}$ and $\mathrm{Ca}$ intracellular, and other increase risks, such as obesity, smoking, and genetic/family history [5], The results of research conducted by (Hafid, 2016) on a group of students without family history of hypertension, the Wilcoxon test results showed that there were systolic blood pressure differences before and after the Cold Pressor Test (CPT) ( $\mathrm{p}<0.05)$, while there were no diastolic blood pressure differences before and after the Cold Pressor Test (CPT) ( $p>0.05)$ [7]. The existence of genetic factors in certain families might cause the family members have the risk of suffering from hypertension due to the increasing intracellular sodium level and low ratio between potassium and sodium. Individuals with family history of hypertension had twice greater risk of suffering from hypertension than those without family history of hypertension[14], The increasing sodium level may cause excessive triouretic hormone excretion. If water excessively comes out of the body, the blood volume and blood pressure may drop. Kidney cells will release the renin enzyme which activates protein in the blood called angiotensinogen to become the active form of angiotensin which will reduce the diameter of blood vessels that blood pressure may increase [5].

The result of this research supported that conducted by Arsyad (2010), which examined the relationship between the history of hypertension in people with hyperactive sympathetic nerves using the Cold Pressor Test (CPT) to predict the sympathetic nerve activity in 40 respondents showing that there was a relationship between the elderly people with history of hypertension and their sympathetic nervous hyperactivity[7]. This is in line with the research conducted by Pai (2011), explaining that a group of respondents with parents suffering from hypertension after undergoing the CPT showed an increasing blood pressure and decreasing heart rate. Thus, the results of this reseach represented the increasing sympathetic activity occurring in a group with parents suffering from hypertension after undergoing the CPT [7].

The result of this study was in line with that conducted by Woisetschläger et al, after undergoing the Cold Pressor Test (CPT), both systolic and diastolic blood pressure more significantly and clearly increased in pregnant women suffering from preeclampsia when compared to the healthy pregnant women (systolic blood pressure: $14.2 \pm 5.5$ versus $8.5 \pm 7.2 \mathrm{mmHg}, \mathrm{P}=0.02$; diastolic blood pressure: $7.3 \pm 4.9$ versus $3.9 \pm 4.7 \mathrm{mmHg}, \mathrm{P}=0.03)$. The heart rate changes were similar in both groups $(8 \pm 2.6$ versus $10.4 \pm 6.4$ beats/ min, not significant). The Cold Pressor Test (CPT) induction to the blood pressure is an effort to trigger the blood pressure's extrinsic reflexes through the sympathetic stimulation in the form of cold temperature (1-40C) to cause pain. In the control group, Cold Pressor Test (CPT) induction will gradually increase the mean arterial pressure in the first and second minutes of CPT due to the increasing vascular resistance caused by the sympathetic stimulation and the increasing cardiac output due to increasing cardiac contractility. The increasing vascular resistance caused by the occurring sympathetic nervous system stimulation due to the increasing the blood vessels' muscle tone. The vascular smooth muscles' autonomous innervation is only originated from the sympathetic nerves, while the heart innervation is originates from the sympathetic and parasympathetic nerves. It proved that Cold Pressor Test (CPT) induction did not significantly affect the heart rate. The results of research on the effect of Cold Pressor Test (CPT) on normal people's cardiovascular control also showed the same results [15].

Cold stimulation resulted from the immersed hands into ice water caused a stimulus in the heart's sympathetic nerves. The stimulus significantly increased the norepinephrine and epinephrine which interacted with the alpha-type adrenergic receptors. This research was manually conducted without utilizing a sophisticated digital device that the researchers explicitly assumed that the undertaken Cold Pressor Test (CPT) technique caused the vasoconstriction effects that the heart more strongly pumped the blood and drained more blood each second. The artery had also lost its flexibility and become more rigid since the flexibility expanded when the heart pumped blood through the arteries that the blood at each heartbeat was forced passing through the narrowing vessels and caused the increasing pressure. Thus, the arterial wall became stiff as the blood pressure increased. When the Cold Pressor Test (CPT) was undergone the small arteries (arterioles) temporarily became stiff due to the stimulation of sympathetic nerves. Family history also possibly caused the increasing autonomic nervous activity, especially the sympathetic nerves in addition to the angiotensinogen genetic role which increased the angiotensin II in blood causing the vasoconstriction of blood vessels and increasing heart rate. This autonomic nervous imbalance was invisible and appeared in the form of various diseases, such as hypertension [7].

\section{CONCLUSION}

Thus, it might be concluded that pregnant women with family history of hypertension had the increasing sympathetic nerves and might be easily detected by undergoing the Cold Pressor Test (CPT) [16], [17][18]

\section{REFERENCES}

The template will number citations consecutively within brackets [1]. The sentence punctuation follows the bracket [2]. Refer simply to the reference number, as in [3] - do not 
use "Ref. [3]" or "reference [3]" except at the beginning of a sentence: "Reference [3] was the first ..."

Number footnotes separately in superscripts. Place the actual footnote at the bottom of the column in which it was cited. Do not put footnotes in the abstract or reference list. Use letters for table footnotes.

Unless there are six authors or more give all authors' names; do not use "et al.". Papers that have not been published, even if they have been submitted for publication, should be cited as "unpublished" [4]. Papers that have been accepted for publication should be cited as "in press" [5]. Capitalize only the first word in a paper title, except for proper nouns and element symbols.

For papers published in translation journals, please give the English citation first, followed by the original foreignlanguage citation [6].

1] V. L. Meah et al., "Functional hemodynamic testing in pregnancy: recommendations of the International Working Group on Maternal Hemodynamics," Ultrasound Obstet. Gynecol., vol. 51, no. 3, pp. 331-340, 2018

[2] V. D. Garovic et al., "Hypertension in pregnancy as a risk factor for cardiovasculardisease later in life," vol. 28, no. 4, pp. 826-833, 2010.

[3] S. Hirpara, R. Ghevariya, P. Ghadia, T. Hada, and N. Pandit, "Study of Risk Factors for Pregnancy Induced Hypertension - A Hospital Based Case Control Study.," Natl. J. Integr. Res. Med., vol. 8, no. 4, pp. 41-44, 2017.

[4] E. F. Laila, "Usia, Paritas, Riwayat Hipertensi Dan Frekuensi Pemeriksaan ANC Terhadap Kejadian Preeklampsiapada Ibu Hamil [Age, Parity, Hypertension History And Anc Examination Frequency On The Incidence Of Pregnant Women With Preeclamsia ], J Kebidanan Malahayati, 2019

[5] L. Atun, T. Siswati, and W. Kurdanti, "Sources of Sodium Intake Sodium Potassium Ratio, Physical Activity , and Blood Pressure of Hypertention Patients Dinas Kesehatan Kabupaten Sleman," Nihrd, vol. 6 , no. 1 , pp. $63-71,2014$
[6] Radar Banyumas, "Angka kematian ibu di purwokerto meningkat [The Increasing Maternal Mortality Rate in Purwokerto].," Radar Banyumas, vol. 4, no. 1, pp. 75-84, 2019.

[7] M. A. Hafid, "Perbandingan Tekanan Darah pada Mahasiswa dengan/dan Tanpa Riwayat Hipertensi di Keluarga setelah Melalui Pembebanan Cold Pressor Test [The Comparison of Students' Blood Pressure with and without Family History of Hypertension after Undergoing the Cold Pressor Test].," J. Islam. Nurs., vol. 1, no. 1, pp. 1-9, 2016.

[8] L. Yanti and M. Ulfah, "Cold Pressor Test for Predicting Risk of Pregnancy Hypertension: A Case Control Study,” 2020.

[9] D. C. Scantlebury et al., "Impact of a history of hypertension in pregnancy on later diagnosis of atrial fibrillation," J. Am. Heart Assoc., vol. 7, no. 10, 2018

[10] E. Nurliawati, ““'Hubungan Antara Preeklampsia Berat Dengan Bayi Berat Lahir Rendah (BBLR) di RSU dr. Soekardjo Kota Tasikmalaya Tahun 2013"," J. Kesehat. Bakti Tunas Husada J. Ilmu-ilmu Keperawatan, Anal. Kesehat. dan Farm., 2015.

[11] S. Hada, S. Amatya, and R. K. Shrestha, "Cold pressor test in borderline hypertensive university students," Kathmandu Univ. Med. J., vol. 14, no. 56, pp. 337-341, 2016.

[12] D. U. Silverthorn and J. Michael, "Cold stress and the cold pressor test,” Am. J. Physiol. - Adv. Physiol. Educ., 2013.

[13] M. A. Hafid, "Perbandingan Tekanan Darah pada Mahasiswa dengan/dan Tanpa Riwayat Hipertensi di Keluarga setelah Melalui Pembebanan Cold Pressor Test," J. Islam. Nurs., 2016.

[14] B. Nuraini, "Risk Factors of Hypertension," J Major., vol. 4, no. 5, pp. 10-19, 2015.

[15] C. Woisetschläger et al., "Increased blood pressure response to the cold pressor test in pregnant women developing pre-eclampsia," J. Hypertens., vol. 18, no. 4, pp. 399-403, 2000.

[16] R. P. Ambasari, H. Sarosa, and Muhtarom, [The Relationship of Family History of Hypertension with Autonomic Nervous Activity]" Sains Med., vol. 5, no. 1, pp. 8-10, 2013.

[17] E. Rosada et al., "Effects Of Cold Pressor Test Induction To Autonomic Activity And Cerebral Haemodynamic In Patients With Migraine In Interictal Phase," pp. 1-15.

[18] L. Mourot, M. Bouhaddi, and J. Regnard, "Effects of the cold pressor test on cardiac autonomic control in normal subjects," Physiol. Res., 2009 